Archived version from NCDOCKS Institutional Repository http://libres.uncg.edu/ir/asu/

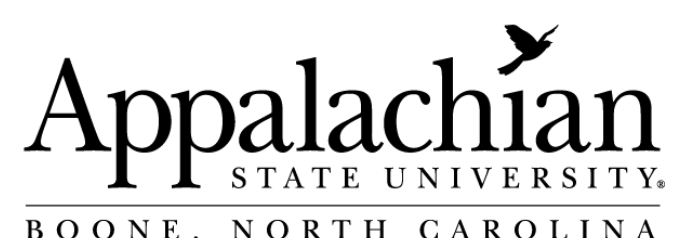

\title{
Advancing Wrongful Conviction Scholarship: Toward New Conceptual Frameworks
}

\author{
By: Robert J. Norris \& Catherine L. Bonventre
}

\begin{abstract}
As wrongful conviction scholarship grows, some scholars have suggested that existing research on miscarriages of justice lacks theoretical grounding and methodological sophistication, arguing that the use of social science theory may help to better understand wrongful convictions. In this article, we suggest that it may be useful to draw upon conceptual frameworks found in traditional criminal justice studies, discuss what such approaches might suggest about miscarriages of justice, and begin to explore the questions or topics they may encourage interested researchers to pursue. Furthermore, through this broad theoretical lens, we can see that criminal justice theory is present, at least implicitly, in some existing innocence literature, and that making such theoretical connections more explicit may help to move the study of wrongful conviction into the mainstream of criminal justice research.
\end{abstract}

Robert J. Norris \& Catherine L. Bonventre (2015) "Advancing Wrongful Conviction Scholarship: Toward New Conceptual Frameworks." Justice Quarterly, 32:6, 929-949, DOI: 


\section{Introduction}

Robert J. Norris is a PhD candidate in the School of Criminal Justice at the University at Albany. He earned his BA in Sociology from the University of North Carolina-Greensboro and his MA from the University at Albany. His research interests include law, society, and politics; miscarriages of justice; social change and legal reform; and criminal justice decision-making. He has authored or co-authored several academic articles and book chapters on state policy responses to wrongful convictions and the decision-making of suspects under investigation and at trial. Catherine L. Bonventre earned her MS in forensic molecular biology at the University at Albany and her JD, with a concentration in criminal law, from Albany Law School. She is currently working on her PhD at the University at Albany School of Criminal Justice. Her research interests include miscarriages of justice; judicial policy-making and implementation in the criminal justice context; crime laboratories and forensic science; and courts and the judicial process. She has worked as a volunteer attorney for the Arizona Justice Project, an organization that helps inmates overturn wrongful convictions. She is licensed to practice law in the state of New York. Correspondence to: R.J. Norris, School of Criminal Justice, University at Albany, 135 Western Ave., Albany, NY, 12222 USA. E-mail: rnorris@albany.edu 
Over the past several decades, few criminal justice issues have captured the attention of practitioners and the public imagination like wrongful convictions. Since 1989, when post-conviction DNA testing was first used to exonerate an innocent person in the USA, we have seen the growth of an innocence movement. Nationwide, advocacy organizations have formed to litigate on behalf of potentially innocent prisoners, increase public awareness about wrongful convictions, and promote criminal justice policy reforms (Zalman, 2006).

The growing academic scholarship on wrongful convictions-that is, scholarship concerning the causes and consequences of convictions of the factually innocent ${ }^{1}$ - has been mostly conducted by legal scholars and psychologists, with relatively little by sociologists, criminologists, and criminal justice researchers. Notably, this literature has mostly lacked the theoretical grounding expected of social scientific inquiry, or, at the very least, failed to make the theoretical connections explicit. Others have discussed the theoretical weaknesses in the current body of miscarriages literature and suggested that researchers transpose frameworks from other areas or disciplines to the study of wrongful convictions (Leo, 2005; Zalman, 2006).

In this essay, we suggest that criminal justice theory, broadly conceived as conceptual frameworks that examine the criminal justice system, is indeed present in some of the miscarriages literature and, if placed at the forefront, may be the most useful avenue for framing such discussions moving forward. We discuss what such frameworks may suggest about miscarriages of justice and what topics or questions they may encourage interested researchers to pursue. The goal of this essay is not to offer a grand theory of wrongful conviction or even a set of testable hypotheses. Rather, we suggest conceptual frameworks through which we might analyze wrongful convictions and criminal justice responses to them. These insights are designed to invigorate theoretical debate and discussion amongst those interested in miscarriages of justice.

We begin with a brief discussion of wrongful convictions with a focus on the existing scholarly research-in short, what we know and how we examine such miscarriages of justice. We then explain why theoretical frameworks addressing the functioning of criminal justice are appropriate for framing discussions about wrongful convictions. Finally, we discuss several theoretical concepts that may be useful in analyzing justice system errors and what such perspectives might say about them.

1. For present purposes, we define "wrongful convictions" as those involving the conviction of factually innocent individuals. While we understand that the phrase "miscarriages of justice" generally includes a wider range of erroneous criminal justice outcomes, including wrongful convictions, we use the terms "miscarriages," "miscarriages of justice," and "wrongful conviction" interchangeably throughout this essay in reference to the foregoing definition of wrongful convictions. 


\section{Wrongful Conviction Scholarship and Legal Discourse}

Though wrongful convictions are not a new phenomenon, the use of DNA has added a new level of scientific certainty to the notion of actual innocence, and wrongful convictions have captured widespread attention. As of August 2013, more than 310 individuals have been exonerated through DNA testing in the USA since 1989 (Innocence Project, n.d.). In addition, the National Registry of Exonerations, a joint project of the University of Michigan Law School and the Center on Wrongful Convictions at Northwestern University School of Law, has compiled hundreds of exonerations achieved through means other than DNA testing, bringing the total number to more than $1,180 .^{2}$ These developments have prompted some to call the current criminal justice period the "Age of Innocence" (Redlich \& Petrila, 2009). The resulting innocence movement has led to policy reforms at multiple levels: to date, the federal government, more than half of the states, and hundreds of individual police agencies have responded to miscarriages of justice. ${ }^{3} \mathrm{~A}$ novel twist to the innocence movement has been the recent creation of "conviction integrity units" within prosecutors' offices (see, e.g. Vance, 2010). These units range in function from investigating post-conviction claims of innocence (e.g. Dallas, TX) to ensuring the accuracy and reliability of forensic evidence (e.g. Wayne County, MI).

Scholarship on wrongful convictions has increased substantially over the past 20 years. ${ }^{4}$ The key foci have been estimating the prevalence of mistaken convictions (e.g. Poveda, 2001; Risinger, 2007) and determining the causes of wrongful conviction (e.g. Gross \& O'Brien, 2008; Harmon, 2001; Harmon \& Lofquist, 2005). In addition, there is a growing body of scholarship addressing the consequences of wrongful conviction (e.g., Grounds, 2004; Westervelt \& Cook, 2010, 2012).

Some scholars have argued, however, that the development of wrongful conviction scholarship has stagnated-at least to the extent that the research has tried to determine the prevalence and causes of errors. One critique described the literature as "theoretically impoverished," and suggested that in order to better understand the "root causes" of wrongful convictions, social scientists needed to "reconceptualize the study of miscarriages of justice" (Leo, 2005, p. 213). At the heart of this critique is causation, specifically, that the extant literature confounds legal causes of wrongful conviction with root causes. Indeed, the factors typically identified as contributors to erroneous

2. These figures are current as of August 2013.

3. The federal Justice for All Act of 2004 (Pub. Law 108-405) provides standards and funding for DNA testing for potential innocents and increased compensation for federal exonerees (Zalman, 2006). At least 34 states and the District of Columbia have now taken at least some steps to prevent erroneous convictions (Norris, Bonventre, Redlich, \& Acker, 2010/2011), and 29 states and the District of Columbia provide compensation for exonerees (Norris, 2012). Furthermore, over 500 police and sheriff's departments now record custodial interviews (Sullivan, 2005; Sullivan \& Vail, 2009).

4. For a discussion of the history of wrongful conviction scholarship, see Leo (2005) and Gould and Leo (2010). 
outcomes-eyewitness misidentifications, false confessions, snitching, and the like-are not really causes in any meaningful social scientific sense, but rather are legal categories that have come to dominate the focus of miscarriages literature. This legal focus has, in turn, fundamentally shaped wrongful conviction discourse. If this area of research is to move forward as a topic for social scientific inquiry, however, researchers must place wrongful convictions in a broader social, cultural, historical, and political context. To do so, scholars should make explicit connections between the object of study and the theoretical underpinnings of criminal justice research. Miscarriages research can benefit tremendously from the use of established theoretical or conceptual frameworks from the social sciences to structure discussions and guide inquiries into the nature of the issue.

\section{Theoretical Perspectives as Conceptual Frameworks}

Theory is often conceived of in purely scientific terms as a generalizable statement about the relationship between two variables that can be tested using quantitative measures and analytic methods, but it is not the only way social scientists have used the term. In this paper, we use the term "theory" to reflect "theoretical perspectives" as advocated by Kraska (2006) and Kraska and Brent (2011). Rather than solely developing quantitatively testable hypotheses, Kraska discusses theoretical perspectives as different ways of thinking about or framing criminal justice issues. This differs from the logical positivist view of theory, but as others have suggested, the positivist perspective has its own disadvantages if adhered to rigidly. Such disadvantages include judging the worth of a theory strictly by how well it fits quantitative data, and drawing a sharp distinction between facts and values, rather than appreciating the role of norms and ideology in theorizing about the controversial, value-laden objects of study inherent to criminal justice (Kraska \& Brent, 2011). Zalman (2007) compliments this perspective, arguing that, "a scientific theory explains the data concerning a phenomenon in a "satisfying" manner" (p. 171). Broader conceptualizations, on the other hand, "do not exhaust a criminal justice scholar's sense of understanding the system," but considering each new perspective "expands one's understanding of criminal justice" (Zalman, 2007, p. 170). In short, theoretical perspectives provide the lenses through which we view phenomena, helping us to better understand the social world (Duffee \& Maguire, 2007; Kraska \& Brent, 2011).

Scholars interested in miscarriages of justice have mostly failed to explicitly use theory in their analyses, instead relying primarily on legal description and interpretation. However, miscarriages research can benefit greatly from scholarship that is grounded in theoretical frameworks from social science, which attempt "to change the way we think about an issue and ultimately change the practical ways we deal with it" (Garland, 1990, p. 277). 


\section{The Utility of Criminal Justice Theory for Innocence Scholarship}

Theoretical perspectives about criminal justice help us make sense of the "criminal justice apparatus" (Kraska \& Brent, 2011, p. 10) and explain "the why of criminal justice behavior" (Kraska, 2006, p. 171). It helps with tracking historical trends and developing an understanding of the nature, development, and implementation of policy and reforms. Such perspectives are thus useful for the study of wrongful convictions. Miscarriages of justice are the productions of a complex criminal justice system, often based upon the decisions made by actors within the system. Furthermore, criminal justice theory is broad, stretching the boundaries of research beyond inquiries into case outcomes. Criminal justice as a discipline involves the use of concepts, ideas, and methods from a host of other fields, an important element for studying a topic as complex as wrongful conviction, which involves multiple arms of the criminal justice system. Any inquiries into the causes of errors must involve at least law enforcement and the courts, while those into the consequences of errors will likely involve corrections and reentry. Yet, all shape and are shaped by laws and reforms implemented by policy-makers and practitioners. Importantly, these elements may be examined at multiple levels, including the decision-making of individual actors, organizational factors, broader social and political themes, and so on. Thus, taking an expansive theoretical approach to the study of miscarriages of justice can help us not only frame discussions of wrongful conviction cases and related policies, but to place the issue in a broader context.

In addition, acknowledging the role of values, norms, and ideological preferences in the process of theorizing is particularly important for analyzing a topic like wrongful conviction, which entails various value-laden ideas and concepts. Much criminal justice scholarship has some prescriptive ideal from which it begins, or an idea about how the system should work (Bernard \& Engel, 2001), and the miscarriages literature is no different. These theoretical perspectives do not suggest that scholars abandon this ideal, but instead make it explicit and acknowledge the role it plays in the development of theory (Bernard \& Engel, 2001; Kraska \& Brent, 2011).

Finally, a broad theoretical approach may help address some of the difficulties associated with miscarriages research. The empirical operationalization of "wrongful conviction" or "innocence" has been debated (see Bedau \& Radelet, 1987; Cassell, 1999; Findley, 2011; Gross, Jacoby, Matheson, Montgomery, \& Patil, 2005). ${ }^{5}$ This debate has, to some extent, been based upon values and ideological preferences, which criminal justice theory embraces rather than rejects. In addition, miscarriages of justice are necessarily hidden

5. For example, some studies (e.g. Bedau \& Radelet, 1987; Free \& Ruesink, 2012) relied upon the researchers' subjective evaluations of cases to determine who was actually innocent and wrongly convicted. Other studies (e.g. Gross et al., 2005) have relied upon official acknowledgment of error in identifying wrongful convictions. 
from view, and there exists no complete data-set of all errors. Thus, any analyses will be conducted on what is likely a very small, non-representative minority of all cases of interest, making it difficult, if not impossible, to adequately develop a definitive causal theory of erroneous outcomes. However, if we view theory as a broad framework that can help us better understand phenomena, even if not amenable to strict quantitative testing, we can move into a new realm of thought and discourse regarding miscarriages of justice, seeing the issue from different angles, and developing new, interesting questions that will expand our understanding of the justice system, its strengths, and its weaknesses.

\section{Criminal Justice Theory and Wrongful Convictions}

Scholars have suggested that because criminal justice is "an inherently multi-theoretic discipline," research may be best served by acknowledging and appreciating the multiple theoretical perspectives that exist rather than searching "for a grand unifying theory" (Zalman, 2007, p. 170). Thus, the key may not be in searching for a definitive causal theory of wrongful conviction, but rather to use broader theoretical orientations to frame discussions of justice system error. Such perspectives are useful for organizing and interpreting thoughts, concepts, and data about criminal justice (Kraska, 2006; Zalman, 2007).

We now discuss five theoretical perspectives ${ }^{6}$ and suggest what each might say about wrongful convictions, as well as the questions they encourage researchers to pursue. ${ }^{7}$

6. Kraska and Brent (2011) identify eight orientations: Rational/Legal; System; Crime Control vs. Due Process; Politics; Socially Constructed Reality; Growth Complex; Oppression; and Late Modernity. We have collapsed the perspectives around some of the key theoretical ideas and have named them based on these underlying ideas. For example, both the Rational/Legal and System orientations draw upon "forced reaction theory." Thus, we discuss these as one perspective based on the underlying theoretical idea. It is important to note that these perspectives (both as Kraska identified them and as we have discussed them here) are not mutually exclusive; there is a fair amount of overlap. However, though they sometimes contain similar ideas, each offers a unique perspective on criminal justice that may contribute independently to our understanding of miscarriages of justice.

7. Many of the ideas about wrongful convictions expressed herein have been discussed by other scholars and/or advocates. For the most part, however, the theoretical aspect of the research has not been made explicit either because it was deemed unimportant for their purposes or the fact that their analysis was rooted in an established theoretical framework was overlooked. There are several exceptions to this, which will be discussed. The overall argument, however, is that these theoretical connections must be made explicit if miscarriages research is to become a prime topical area of social scientific inquiry in the mainstream of criminological and criminal justice scholarship. 


\section{Forced Reaction Theorizing and the Purpose of Criminal Justice}

Both the rational/legal and systems orientations invoke what Kraska and Brent (2011) call "forced reaction theory" (p. 20) in explaining the behavior of criminal justice. Theoretically simple, this perspective sees the criminal justice system and the agencies and individuals that work within it as mostly well-intended, rational decision-makers who respond to outside influences in attempting to ensure the safety of society. Thus, the rapid expansion of criminal justice over the past several decades is viewed as an inescapable reaction to worsening crime and security problems, or at least perceptions of such. The rational/legal perspective emphasizes rules and policies and the protection of individuals' legal rights, with the key goal of seeking justice by punishing the guilty while sparing as many innocent as possible within legal rules and procedures. The system perspective also emphasizes the efficiency with which cases are processed, as the parts of the system seek equilibrium in attempting to maximize efficiency while maintaining a high level of quality outcomes (Bernard, Paoline, \& Pare, 2005). These perspectives, then, have some interesting implications for discussions of miscarriages of justice and wrongful convictions.

On its face, forced reaction theorizing might see wrongful convictions as simply an unfortunate, but not particularly egregious, byproduct of a criminal justice system that is intended to control crime in order to protect society. This perspective would thus encourage a less critical view of justice system errors as is currently the norm in the miscarriages literature. Mistakes made on the part of criminal justice actors that may lead to erroneous outcomes might be viewed as well-intended behaviors of individuals attempting to ensure the safety and security of citizens. For example, the behaviors of prosecutors or police in a small town, where a high-profile case generates public concern and demand for punishment, might be seen as a normal reaction to ensure the peace and stability of the community. Thus, so long as the rights of the accused are not violated, such cases would not be seen as instances of governmental misconduct, as they are often described in the wrongful conviction literature, but as inescapable human reactions that occur in the face of crime and public outcry and within an extraordinarily complex system that allows a high level of discretion. Indeed, forced reaction theorists might suggest that any process as complex as that in criminal justice is bound to produce some erroneous outcomes. Rather than heavily and negatively criticizing practitioners for their decisions and behaviors, ${ }^{8}$ then, this perspective encourages scholars to attempt to understand the larger context within which such decisions are made and how these behaviors may have been shaped by those of another person or organization in the system, realizing that such behaviors and decisions rarely occur out of malice, but are

8. For a review of the wrongful conviction literature that engages in a fault-based discourse on prosecutors, see, Burke (2010). 
rational attempts to achieve the systemic goals of crime control and efficient processing. As Bandes (2006) observed, "[T]he focus on fault and blame is in many respects counterproductive" and "it is a particularly unhelpful focus where...the problem is a failure to act, a failure to consider alternative scenarios, or a failure to reconsider erroneous conclusions. Such inaction is usually a collective effort, based on deeply entrenched bureaucratic incentives and very difficult to trace to individuals, since inaction is achieved largely through deflection of responsibility" (p. 485). Along these lines, Medwed (2012) suggests that the dual role of prosecutors-that is, they are supposed to ensure justice and fairness on the one hand while being agents of and advocates for the government on the other-creates pressures that may be at the root of certain prosecutorial behaviors that may lead to wrongful convictions.

The forced-reaction perspective yields a more fundamental implication for the discourse surrounding miscarriages of justice and the purpose of criminal justice more generally. To date, most miscarriages research has focused on factually erroneous convictions, with an implicit or explicit assumption that the worst injustice the state could commit is the punishment of the innocent. In other words, protecting potential innocents should be the highest priority of the system. Historically, however, most forcedreaction theorizing has assumed that the primary purpose of criminal justice is to control crime and protect society, and to do so efficiently. Thus, if we accept an error rate in the range of $1 \%$, then an argument can be made that wrongful convictions are not, in fact, a major problem, at least not to the extent that extensive reform should target them, but rather should focus on more pressing issues. Indeed, the systems perspective understands the desire within criminal justice to maintain equilibrium and efficiency, sometimes to the extent that efficient processing becomes a higher priority than achieving an accurate outcome (Bernard et al., 2005). This distinction can reshape discussions of miscarriages of justice and initiate a debate about the nature and extent of the "problem" of wrongful convictions. Forst's (2010/2011) analytical framework, for example, views both errors of due process (which include convicting the innocent) as well as errors of impunity (which include the failure to sanction culpable offenders) as existing along a continuum bounded by the most egregious examples of either type of error at the ends. The remaining cases along the continuum are "the natural result of benign imperfections, resource constraints, and a system of justice that relies on probabilistic rules of conviction" (Forst, 2010/ 2011, p. 1214). Such a fundamental debate-regarding the primary purpose of criminal justice-can and should occur amongst social scientists interested in miscarriages of justice. The essence of such a debate would be Blackstone's (1765-1769) stated principle that "it is better that ten guilty persons escape than that one innocent suffer." Indeed, any number may 
justifiably replace the subjective value of "ten" (Volokh, 1997). ${ }^{9}$ The forced reaction perspective, then, encourages scholars to ask more fundamental questions concerning legal theory and criminal justice when approaching the study of justice system errors.

This perspective also provides a useful starting point for understanding innocence-related policy reforms as well. Just as the increases in punitive punishment practices may be seen as legal reactions to an increased crime and security problem, reforms designed to prevent, discover, and remedy erroneous convictions may be seen as necessary reactions to increased numbers of exonerations. In the face of mounting exonerations of innocent persons, legislators and criminal justice agencies react in order to ensure that wrongful convictions are kept to a minimum and those that do occur are discovered. It also encourages evaluation studies, or applied examinations of "what works," a common type of research within the systems orientation (Kraska \& Brent, 2011). Such analyses should be conducted as more and more states and agencies implement reforms designed to reduce wrongful convictions. The importance of such research to wrongful convictions is highlighted by the recent exchange between Clark (2012a, 2012b) and Wells, Steblay, and Dysart (2012), in which they debate the costs and benefits of eyewitness identification procedure reforms.

Finally, the forced-reaction perspective, particularly within a systems orientation, encourages experts to think more deeply about reform recommendations, focusing not only on what might increase the accuracy of outcomes, but also maintaining (or improving) processing efficiency, and considering the broader social costs of such policies (Forst, 2010/2011). An appreciation of the desire for equilibrium among the various components of the system may thus be useful in understanding any institutional or organizational resistance to innocence-related policy reforms, as certain changes may upset, or may be perceived as upsetting, the balance or equilibrium of the system.

\section{Value Preferences and the Pendulum of Criminal Justice}

As Packer (1968) described decades ago, criminal justice behavior may not be best explained as a forced reaction to crime and justice issues, but rather by

9. As Leo (2005) notes, the Blackstone principle, or some variation of it, has been the starting point of many of the existing books on wrongful convictions. He describes the "familiar plot" (p. 203) of these works as first announcing that in the American criminal justice system, it is better that some number of guilty men (ranging from 10 to 1000) escape than that one innocent be convicted, then pointing out the protections designed to ensure this, and then arguing that wrongful convictions occur regularly but largely go unnoticed. This was then followed by a description of innocence cases, the causes of the errors, and reforms that might prevent them. Though Leo offers a sound critique of the "familiar plot" and makes several suggestions for moving the study of miscarriages of justice forward, he does not acknowledge that the fundamental principles at the heart of much miscarriages scholarship, such as the Blackstone ratio, as well as the definitional issues associated with such research, are matters in and of themselves that can and should be discussed and debated by social scientists in light of our theoretical perspectives. 
the value choices made by the government and by society more generally. The choice he described is between two abstract sets of values that he called crime control (CC) and due process (DP), the former emphasizing the suppression of crime as the primary criminal justice function, the latter focusing on individual freedom from unjust state actions. An emphasis on crime control thus values the efficient production of high conviction rates, speed and finality in convicting and sentencing offenders, informal fact-finding, and the screening out of most innocent persons, while it de-emphasizes formalities and controls in the process. A due process focus, on the other hand, values procedural safeguards, transparency, and the appeals process, and takes into account the fallibility of informal fact-finding and the resulting need for formal, adversary procedures.

Regarding miscarriages of justice, the crime control orientation is more optimistic about the low probability of error and will accept a certain amount of error to the point at which it impedes crime-reduction goals (Packer, 1968). A due process emphasis insists that mistakes be prevented to the extent possible, even at the expense of processing efficiency. Packer's framework has been applied to the study of wrongful convictions by Huff and colleagues (Huff, Rattner, \& Sagarin, 1996), who suggest that the system's preferences will determine our tolerance of justice system error. Though they do not fully explicate their use of this framework, the lens is a useful one through which scholars might view miscarriages of justice, promoting a broader view of errors that takes into account the context in which they occur. Indeed, Packer (1968) did not argue that there is or should be a balance between the two models; rather, he suggested that the sociopolitical culture of a particular historical period swings the pendulum in one direction or the other. A higher emphasis on crime control values leads to a larger, more powerful criminal justice apparatus and, for the study of miscarriages of justice, an increased tolerance of justice system error, while an emphasis on due process values leads to a more restricted apparatus and a desire to reduce error as much as possible. The government chooses which value set will drive criminal justice behavior, but these choices hinge on broader societal shifts towards one value set or the other. To better understand wrongful convictions, then, scholars may want to step back and historically view errors in light of the broader contexts in which they occur, including the entire range of criminal justice practices of different periods and larger social and cultural shifts more generally.

It is likely that lawmakers and practitioners who make the decisions that drive criminal justice practices face, at least to some degree, goal conflict and mixed messages as value-sets compete for priority. Social scientists should seek to understand how these competing goals are balanced by those with the power to affect criminal justice practices. This is a particularly interesting topic for the study of miscarriages of justice, as some have suggested that the innocence movement has merged the values of crime control and due process (Findley, 2008). 


\section{The Political Nature of Miscarriages of Justice}

A political orientation views all criminal justice activity and thinking as interest-based, with influences at all levels of the criminal justice apparatus and ideology viewed as "the permanent hidden agenda of criminal justice" (Miller, 1973, p. 142). The purpose of criminal justice is thus contingent on the political climate of a particular period, to be used as a means of gaining political capital. Practitioners and policy-makers involved in criminal justice act based on their ideological preferences and political calculations, rather than focusing on what is necessarily the best or most effective solution. For example, the massive expansion of criminal justice over the past several decades may be viewed as the result of general ideological shifts and politicians exploiting the problem of crime and public fears, rather than enacting the most sensible policies (see, e.g. Zimring, Hawkins, \& Kamin, 2001). Research in this area has focused on, among other things, local democratic processes, political dynamics, and the role of interest groups.

A political focus may be useful in examining miscarriages of justice. Researchers have often examined the community contexts within which decisions are made by local criminal justice actors (e.g. Cole, 1970; Eisenstein, Flemming, \& Nardulli, 1988), which sometimes lead to wrongful convictions. Thus, this perspective may be particularly useful in studying the production of erroneous outcomes that are the result of mistakes or misconduct on the part of such actors, whose decisions are not made lightly or in a vacuum, but exist within a political context and may be done to maximize the political benefit for the individual. For example, if an egregious crime stirs community outrage, a prosecutor may feel pressure to secure a conviction and punishment at all costs. Thus, methods that are perceived to help accomplish this goal, appease the community, and, for most prosecutors, appeal to their constituency and gain political support, may be used even if they contrast with considerations of ethics or accuracy. The local community context may also shape policy and practical reforms to address wrongful convictions if there is local concern about the issue. For instance, if a high-profile exoneration occurs after a conviction that was based in part on police misconduct, the local agency may feel some pressure to implement a new practice or set of rules to help prevent similar cases in the future or if those making the decisions perceive such a reform to be politically advantageous.

A political orientation may be useful in examining innocence-related policies more broadly as well. Much research has focused on the effects of statehouse politics and interest groups on policy outcomes (e.g. Barrilleaux \& Berkman, 2003; Davies \& Worden, 2009; Ornstein \& Elder, 1978; Walker, 1983). This may be applicable to innocence reforms as well. We might expect, based on ideological considerations, that more progressive criminal justice reforms would be associated with Democratic Party control (Owens \& Griffiths, 2011/2012). Furthermore, innocence-related interest groups, including statewide innocence 
projects and criminal justice reform organizations, have been founded nationwide. Where these groups are most numerous, active, and influential, we might expect broader innocence-related reform policies. Thus, scholars can draw on conceptual frameworks and methods used in public policy and political science to understand state responses to miscarriages of justice.

Overall, the politics orientation seems to suggest that there may be a certain climate that is most apt for successful innocence reform efforts. Depending on what particular aspect of the political perspective is examined, this climate might change, but it may include an emphasis on "leftist" (Miller, 1973) ideals and values, and interest groups that have some power (e.g. the Innocence Project). This perspective also encourages scholars to realize that certain changes and reforms may only be symbolic responses to wrongful convictions. Though the influence of symbolic politics is likely less powerful in regards to innocence reforms than with law-and-order policies, it is conceivable that if exonerations produce, or are perceived as producing, a legitimacy crisis for the criminal justice system, politicians may attempt to exploit the problem for political gain if they believe the public is vulnerable to symbolic messages and sees a potential for an increase in political capital. ${ }^{10}$ Though pessimistic, this viewpoint might suggest that truly meaningful change may require a broader movement that is highly ideological (Miller, 1973), such as that which some innocence reformers seem to be attempting to spark through their transformative political rhetoric. ${ }^{11}$

\section{Constructing Crime, Innocence, and Justice}

We often speak about criminal justice in absolute facts, of crime and justice as distinct reality. A social constructionist approach, however, does not see this reality as predetermined, but instead as an interpretive construct, and seeks to understand "how the facts of crime and crime control are produced" (Rafter, 1990, p. 376). Research in this tradition focuses on how social problems are constructed, taking a critical approach to understanding crime and justice issues. Because it is socially constructed, the purpose of criminal justice is relative, with definitions of crime and justice driven by moral entrepreneurs and the media. Some in this line of thinking suggest that practitioners create and promote myths in order to maintain legitimacy; others suggest that it is done simply to expand the criminal justice system, as "a bureaucracy's most basic instinct is to survive and grow" (Kraska \& Brent, 2011, p. 195).

10. For an in-depth discussion of symbolic politics and law-and-order policies, see Scheingold (1984). We suggest that the influence of symbolic politics on innocence reforms may be less dramatic than for crime control policies because crime, unlike wrongful conviction, is a very public and highly salient political issue.

11. As Zalman (2006) points out, the rhetoric often used "suggests that emotions among innocence activists are akin to those of participants in reformist social movements" (pp. 472-473). 
Through this framework, then, we might understand the potential rise in wrongful convictions that result from the expansion of criminal justice more generally. If indeed criminal justice is designed for financial and political gain, to build bureaucracy, and ultimately to increase in size and power, then any increase in the sheer number of erroneous convictions is a mere byproduct. With such an emphasis on growing the criminal justice system, concerns about innocents getting caught up in the system may fall by the wayside. Like earlier orientations, then, this viewpoint challenges us to have a debate about the fundamental purpose of criminal justice. Unlike the earlier ones, however, social constructionists would take a much more critical approach.

We might also understand certain classes of wrongful convictions through this lens. Theorists have often spoke of moral panics, which arise when claimsmakers bring urgent social problems couched in non-neutral terms to society's attention resulting in police, prosecutors, or legislatures making short-sighted modifications in procedures or laws to address the problem (Grometstein, 2008; on moral panics generally, see Goode \& Ben-Yehuda, 1994). Grometstein (2008) demonstrated the utility of moral panic theory to wrongful conviction research in light of certain correlates of wrongful conviction (e.g. overzealous prosecution, false confessions, and forensic errors) in her analysis of the organized child sexual abuse cases in which several day care workers were falsely accused and convicted of child abuse.

A social constructionist perspective may also be used to evaluate the legitimacy of the innocence movement itself. If crime and justice are socially constructed, and the problem of crime over the past several decades can be viewed as a myth exploited by the media and practitioners for political or other motives, then the innocence movement can also be viewed through such a lens. Indeed, critics of the movement might contend that there is in fact no innocence problem, but rather a myth that has been created and exploited by opportunistic advocacy groups, activists, and politicians, particularly those opposed to capital punishment (Marquis, 2005). At the very least, they might suggest that innocence is too unclear, and that the number of wrongful convictions is so small as to not warrant significant reform, again with the implication that the real innocence "problem" is but a creation of opportunistic activists (Cassell, 1999, 2004).

The utility of a social constructionist perspective goes beyond investigating broad myths of crime, justice, and, in this case, innocence. This perspective encourages researchers to examine occupational subcultures and the myths they entail, their formation, and maintenance. Scholars often suggest the leading causes of wrongful conviction include police, prosecutorial, and forensic misconduct. However, these issues are then rarely examined in light of the organization or agency in which they occurred. In other words, innocence scholars often take for granted that such misconduct has at its heart either malice or mistaken negligence, but rarely look at the environment in which such misconduct was produced. Thompson (2008), for example, noted that discourse on the role of forensic science in wrongful convictions that highlights 
individual instances of forensic misconduct or mistakes, rather than the organizational and cultural environments in which these events occur, does little to explain them. Lofquist (2001) uses several theories of organizational wrongdoing to examine the wrongful conviction of Dale Johnston, from the police investigation through their construction of the case narrative. He argues that this perspective sees the error not as the result of malice or ill intent on the part of individual police officers, but as the product of the routine operations of the agency. There is also a long literature in criminal justice that examines "police culture," or the shared values among law enforcement officers that may impact their behavior (e.g. Skolnick, 1994; Westley, 1970), which may be useful for studies of the police role in wrongful convictions.

Organizational perspectives have been rare in wrongful conviction studies, but analysis at this level is crucial if we are to understand wrongful convictions. As Thompson (2008) observed, "We can generate more interesting hypotheses about the causes of problems, and identify more promising solutions, by shifting our focus from individual 'bad apples' to the systems of incentives and disincentives within which police, forensic scientists, lawyers, and judges operate" (p. 1049).

\section{Critical Criminology, State Oppression, and Wrongful Conviction}

Much criminological research has taken a critical approach focused on the government's construction of and response to crime. A large amount of this scholarship has focused on the ways in which socially marginalized and disadvantaged populations, such as the poor and racial minorities, have been oppressed through the state's excessive, and sometimes unjust, use of its policing powers, and has been critical of the massive expansion of the criminal justice system over the past several decades (e.g. Reiman \& Leighton, 2010; Simon, 1993). Research in this tradition has often focused on the intersections of race, class, and gender in shaping criminal justice outcomes, arguing that these factors shape definitions of crime and justice and focusing on the oftenunconscious institutional biases that lead to oppressive end-results (e.g. Shelden, 2008).

The critical focus on state behavior present in this literature can be utilized as a lens through which to view justice system errors and state responses to them. The wrongly convicted, like most of those involved in the criminal justice system in general, tend to be poor and are most likely to come from ethnic and racial minority groups (Gross \& Schaffer, 2012; Innocence Project, n.d.). Though this point is often made, it is rarely explored in any real depth. Evidence suggests that cross-racial eyewitness identifications are more likely to be mistaken (e.g. Meissner \& Brigham, 2001; Wells \& Olson, 2001) and that black suspects may be more likely to falsely confess (e.g. Gross et al., 2005; Najdowski, 2011), but few have placed racial disparities in wrongful convictions in a broader context. Anderson and Anderson (2009) attempt to do 
exactly this, arguing that the same forces of bias and inequality that shape criminal justice behavior in general also shape wrongful convictions, which are often the result not of innocent errors, but deliberate actions on the part of criminal justice actors. Their study focuses on Canada, but a similar lens could be used to analyze the issue in the USA and elsewhere. For instance, Duru (2004) roots wrongful convictions in the racial history of the USA, arguing that the history of lynching and racial stereotypes in popular culture has laid a groundwork for erroneous justice outcomes. In particular, Duru argues that the "myth of the bestial black man" (passim) that was so persistent in American history still exists to some extent, and can influence case outcomes.

An oppression framework may also be used to better understand the effects of wrongful convictions on exonerees, their families, and others. For instance, Westervelt and Cook (2010) use a state-harms framework to analyze the struggles faced by exonerees after release. Framing exonerees in this way focuses on the tendency for them to be among the least socially powerful and makes central the state's role, highlighting the fact that the suffering and struggles faced by exonerees comes at the hands of state actors. The Innocence Project (2009), the largest national advocacy organization dedicated to wrongful convictions, has also used the language of critical criminology in suggesting that a reason exoneree compensation may often be overlooked is the fact that those who would receive it tend to be poor minorities.

The critical perspective, like the others discussed in this essay, can be very useful for framing discussions about and research on wrongful convictions. But, it is up to scholars to use these (and other) perspectives. In order to expand theory in the innocence literature, scholars must make a point to work across disciplinary lines and draw upon existing scholarship to better understand miscarriages of justice.

\section{Moving Forward: Expanding Conceptual Frameworks And Building Interdisciplinary connections}

In this essay, we have suggested that several key theoretical perspectives from the criminal justice literature may be useful as conceptual frameworks for miscarriages scholarship, and we have identified examples from the extant literature where those perspectives have been present, both implicitly and explicitly. These perspectives encourage discussion and debate, and generate new questions that can be asked about miscarriages of justice. The forced reaction perspective, for example, may encourage a fundamental debate among innocence scholars about the scope and nature of the "problem" and the fundamental purpose of criminal justice. Other orientations, such as the value preferences model, encourage researchers to step back and take a macro-level approach that goes beyond aggregating descriptive factors about wrongful convictions and exonerations. These perspectives, then, can contribute to and help "reconceptualize" (Leo, 2005, p. 213) miscarriages scholarship. To do this, will require 
scholars interested in wrongful convictions and related issues to broaden their perspectives by reaching across disciplinary boundaries. The frameworks discussed are necessarily interdisciplinary-such broad perspectives must be. Thus, innocence scholars (whether their scholarship is rooted in law or social science) should continue to develop ties across academic fields to develop a better understanding of wrongful convictions and "achieve a higher degree of sophistication, generality, and respect" (Leo, 2005, p. 212). Although miscarriages scholarship has come from researchers in a number of different disciplines, more can be done to draw upon the relevant fundamental literatures from each. Perhaps an example will better explain what we mean when we propose that interdisciplinary bridges continue to be constructed and expanded.

Let us consider how connecting classic criminal justice scholarship with psychology and law research might provide a better understanding of interrogations and false confessions, one of the leading contributing factors to wrongful convictions. As mentioned earlier, in criminal justice scholarship, there is a classic literature on "police culture" that suggests that law enforcement officers share a set of perspectives, norms, and values that form as a result of their adaptations to their work environments and the hostility they often encounter (e.g. Paoline, Myers, \& Worden, 2000; Skolnick, 1994; Westley, 1970). Adherence to this culture has been linked to certain behavioral outcomes for officers, such as the increased use of coercive authority (Terrill, Paoline, \& Manning, 2003). Psychology and law scholars, on the other hand, have long studied criminal interrogations. Certain concepts from the psychological literature, such as generalized communicative suspicion and the investigator bias effect (e.g. Levine \& McCornack, 1991; Masip, Alonso, Garrido, \& Antón, 2005; Meissner \& Kassin, 2002), can be construed as part of traditional police culture. At the very least, these literatures overlap, share some common themes, and can inform each other in important ways. However, research from these two perspectives rarely, if ever, speak to one another. Yet, it seems obvious - the police occupational subculture undoubtedly affects professional behavior such as suspect interviews and interrogations, and aspects of interrogations and the officers who conduct them surely are entwined in such a subculture. And let us not exclude the importance of law to these matters. Entwined in any discussion of false confessions are legal matters, from fundamental issues regarding Miranda requirements to vulnerable populations and parental involvement. Countless legal scholars have tackled these issues along with social and cognitive psychologists. Thus, a dialog between these scholarly areas would be extremely useful to deepening our understanding of criminal interrogations and in turn help us gain a better sense of the phenomenon of false confessions. To take this even further, such interdisciplinary thinking flows naturally into policy recommendation, adoption, and implementation, matters to which political science research can speak directly. Interdisciplinary thinking of this nature will deepen ties between scholarly communities, help ground wrongful scholarship in the fundamental thinking of these disciplines, and help it become a mainstream topic for criminal justice research. 
It is not only important to build connections between disciplines within the academic community, but also between researchers and practitioners. As discussed earlier, there are numerous difficulties associated with the study of wrongful convictions, including the lack of data about the cases. While the development of the National Registry of Exonerations has provided researchers with an incredible source of information about known wrongful convictions, organizations such as the Innocence Project still have a wealth of information that has yet to be fully exhausted. It is crucial that researchers build strong working relationships with such organizations. The knowledge, experience, and data from such organizations, combined with the theoretical and methodological training of social scientists, are a recipe to develop a deeper understanding of justice system errors.

We do not mean to suggest that building these connections will be especially easy or that every researcher should venture beyond the disciplinary boundaries with which they are comfortable. And we certainly are aware that it will not erase the myriad theoretical, methodological, and practical difficulties associated with the study of wrongful convictions. However, we firmly believe that making these connections is an important step towards expanding the theoretical foundations, and thus our overall understanding, of miscarriages of justice.

\section{Conclusion}

In the past several years, we have seen a number of encouraging developments in miscarriages scholarship. Research continues to expand beyond the case-study approach of identifying the causes of wrongful conviction as scholars ask new, exciting questions about miscarriages of justice. Still, it is imperative that we continue to advance our theoretical understanding of the issue. As noted earlier, mistaken convictions have long been a fundamental concern of our criminal justice system, but the modern innocence movement has reshaped our notions about justice both in theory and in practice. It is now time for scholars to use theoretical frameworks to enhance our understanding of wrongful convictions.

\section{Acknowledgments}

The authors wish to thank Dr. James Acker and the anonymous reviewers for their insightful comments on this manuscript. An earlier version of this paper was presented at the American Society of Criminology Annual Meeting.

\section{References}

Anderson, D., \& Anderson, B. (2009). Manufacturing guilt (2nd ed.). Black Point: Fernwood. 
Bandes, S. (2006). Loyalty to one's convictions: The prosecutor and tunnel vision. Howard Law Journal, 49, 475-494.

Barrilleaux, C., \& Berkman, M. (2003). Do governors matter? Budgeting rules and the politics of state policymaking. Political Research Quarterly, 56, 409-417.

Bedau, H. A., \& Radelet, M. L. (1987). Miscarriages of justice in potentially capital cases. Stanford Law Review, 40, 21-179.

Bernard, T. J., \& Engel, R. S. (2001). Conceptualizing criminal justice theory. Justice Quarterly, 18, 1-30.

Bernard, T. J., Paoline, E. A., \& Pare, P. (2005). General systems theory and criminal justice. Journal of Criminal Justice, 33, 203-211.

Blackstone, W. (1765-1769). Commentaries on the laws of England. Oxford: Clarendon Press.

Burke, A. S. (2010). Talking about prosecutors. Cardozo Law Review, 31, 2119-2137.

Cassell, P. G. (1999). The guilty and the "innocent": An examination of alleged cases of wrongful conviction from false confessions. Harvard Journal of Law \& Public Policy, 22, 523-597.

Cassell, P. G. (2004). In defense of the death penalty. In H. A. Bedau \& P. G. Cassell (Eds.), Debating the death penalty: Should America have capital punishment? The experts on both sides make their case (pp. 183-217). New York, NY: Oxford University Press.

Clark, S. E. (2012a). Costs and benefits of eyewitness identification reform: Psychological science and public policy. Perspectives on Psychological Science, 7, 238-259.

Clark, S. E. (2012b). Eyewitness identification reform: Data, theory, and due process. Perspectives on Psychological Science, 7, 279-283.

Cole, G. F. (1970). The decision to prosecute. Law \& Society Review, 4, 331-344.

Davies, A. L. B., \& Worden, A. P. (2009). State politics and the right to counsel: A comparative analysis. Law \& Society Review, 43, 187-220.

Duffee, D. E., \& Maguire, E. R. (Eds.). (2007). Criminal justice theory: Explaining the nature and behavior of criminal justice. New York, NY: Routledge.

Duru, N. J. (2004). The Central Park Five, the Scottsboro Boys, and the myth of the bestial black man. Cardozo Law Review, 25, 1315-1346.

Eisenstein, J., Flemming, R. B., \& Nardulli, P. F. (1988). The contours of justice: Communities and their courts. Boston, MA: Little, Brown.

Findley, K. A. (2008). Toward a new paradigm of criminal justice: How the innocence movement merges crime control and due process. Texas Tech Law Review, 41, 133175.

Findley, K. A. (2011). Defining innocence. Albany Law Review, 74, 1157-1208.

Forst, B. (2010/2011). Managing miscarriages of justice from victimization to reintegration. Albany Law Review, 74, 1209-1275.

Free, M. D., \& Ruesink, M. (2012). Race and justice: Wrongful convictions of African-American men. Boulder, CO: Lynne Rienner.

Garland, D. (1990). Punishment and modern society: A study in social theory. Chicago, IL: The University of Chicago Press.

Goode, E., \& Ben-Yehuda, N. (1994). Moral panics: The social construction of deviance. Cambridge, MA: Wiley.

Gould, J. B., \& Leo, R. A. (2010). One-hundred years later: Wrongful convictions after a century of research. Journal of Criminal Law and Criminology, 100, 825-868.

Grometstein, R. (2008). Wrongful conviction and moral panic: National and international perspectives on organized child sexual abuse. In C. R. Huff \& M. Killias (Eds.), Wrongful conviction: International perspectives on miscarriages of justice (pp. 11-32). Philadelphia, PA: Temple University Press. 
Gross, S. R., Jacoby, K., Matheson, D. J., Montgomery, N., \& Patil, S. (2005). Exonerations in the United States 1989 through 2003. Journal of Criminal Law and Criminology, 95, 523-553.

Gross, S. R., \& O'Brien, B. (2008). Frequency and predictors of false conviction: Why we know so little, and new data on capital cases. Journal of Empirical Legal Studies, 5, 927-962.

Gross, S. R., \& Schaffer, M. (2012). Exonerations in the United States, 1989-2012. Retrieved from National Registry of Exonerations: http://www.exonerationregistry. org

Grounds, A. (2004). Psychological consequences of wrongful conviction and imprisonment. Canadian Journal of Criminology and Criminal Justice, 46, 165-182.

Harmon, T. R. (2001). Predictors of miscarriages of justice in capital cases. Justice Quarterly, 18, 949-968.

Harmon, T. R., \& Lofquist, W. S. (2005). Too late for luck: A comparison of post-Furman exonerations and executions of the innocent. Crime and Delinquency, 51, 498-520.

Huff, C. R., Rattner, A., \& Sagarin, E. (1996). Convicted but innocent: Wrongful conviction and public policy. Thousand Oaks, CA: Sage.

Innocence Project (n.d.). Retrieved from http://www.innocenceproject.org/

Innocence Project. (2009). Making up for lost time: What the wrongly convicted endure and how to provide fair compensation. Retrieved from http:///www.innocenceproject.org/docs/Innocence_Project_Compensation_Report.pdf

Kraska, P. B. (2006). Criminal justice theory: Toward legitimacy and an infrastructure. Justice Quarterly, 23, 167-185.

Kraska, P. B., \& Brent, J. J. (2011). Theorizing criminal justice (2nd ed.). Long Grove, Il: Waveland Press.

Leo, R. A. (2005). Rethinking the study of miscarriages of justice: Developing a criminology of wrongful conviction. Journal of Contemporary Criminal Justice, 21, 201223.

Levine, T. R., \& McCornack, S. A. (1991). The dark side of trust: Conceptualizing and measuring types of communicative suspicion. Communication Quarterly, 39, 325-340.

Lofquist, W. S. (2001). Whodunit? An examination of the production of a wrongful conviction. In S. D. Westervelt \& J. A. Humphrey (Eds.), Wrongly convicted: Perspectives on failed justice (pp. 174-196). New Brunswick, NJ: Rutgers University Press.

Marquis, J. (2005). The myth of innocence. Journal of Criminal Law \& Criminology, 95, 501-521.

Masip, J., Alonso, H., Garrido, E., \& Antón, C. (2005). Generalized communicative suspicion (GCS) among police officers: Accounting for the investigator bias effect. Journal of Applied Social Psychology, 35, 1046-1066.

Medwed, D. S. (2012). Prosecution complex: America's race to convict and its impact on the innocent. New York, NY: NYU Press.

Meissner, C. A., \& Brigham, J. C. (2001). Thirty years of investigating the own-race bias in memory for faces: A meta-analytic review. Psychology, Public Policy, and Law, 7, 3-35.

Meissner, C. A., \& Kassin, S. M. (2002). "He's guilty!": Investigator bias in judgments of truth and deception. Law and Human Behavior, 26, 469-480.

Miller, W. (1973). Ideology and criminal justice policy: Some current issues. Journal of Criminal Law and Criminology, 64, 141-154.

Najdowski, C. J. (2011). Stereotype threat in criminal interrogations: Why innocent black suspects are at risk for confessing falsely. Psychology, Public Policy, and Law, 17, 562-591.

Norris, R. J. (2012). Assessing compensation statutes for the wrongly convicted. Criminal Justice Policy Review, 23, 352-374. 
Norris, R. J., Bonventre, C. L., Redlich, A. D., \& Acker, J. R. (2010/2011). "Than that one innocent suffer": Evaluating state safeguards against wrongful conviction. Albany Law Review, 74, 1301-1364.

Ornstein, N. J., \& Elder, S. (1978). Interest groups, lobbying, and policymaking. Washington, DC: Congressional Quarterly Press.

Owens, M. L., \& Griffiths, E. (2011/2012). Uneven reparations for wrongful convictions: Examining the state politics of statutory compensation legislation. Albany Law Review, 75, 1283-1327.

Packer, H. L. (1968). The limits of the criminal sanction. Stanford, CA: Stanford University Press.

Paoline, E. A., Myers, S. M., \& Worden, R. E. (2000). Police culture, individualism, and community policing: Evidence from two police departments. Justice Quarterly, 17, 575-605.

Poveda, T. G. (2001). Estimating wrongful convictions. Justice Quarterly, 18, 689-708.

Rafter, N. H. (1990). The social construction of crime and crime control. Journal of Research in Crime and Delinquency, 27, 376-389.

Redlich, A. D., \& Petrila, J. (Eds.). (2009). Special issue: The age of innocence: Miscarriages of justice in the 21st Century. Behavioral Sciences and the Law, 27, 297-489.

Reiman, J., \& Leighton, P. (2010). The rich get richer and the poor get prison: Ideology, class, and criminal justice (9th ed.). Upper Saddle River, NJ: Prentice-Hall.

Risinger, D. M. (2007). Innocents convicted: An empirically justified factual wrongful conviction rate. Journal of Criminal Law and Criminology, 97, 761-806.

Scheingold, S. A. (1984). The politics of law and order: Street crime and public policy. New York, NY: Longman.

Shelden, R. G. (2008). Controlling the dangerous classes: A history of criminal justice in America (2nd ed.). Upper Saddle River, NJ: Prentice-Hall.

Simon, J. (1993). Poor discipline: Parole and the social control of the underclass, 18901990. Chicago, IL: University of Chicago Press.

Skolnick, J. H. (1994). Justice without trial: Law enforcement in democratic society (3rd ed). New York, NY: Wiley.

Sullivan, T. P. (2005). Electronic recording of custodial interrogations: Everybody wins. Journal of Criminal Law and Criminology, 95, 1127-1144.

Sullivan, T. P., \& Vail, A. W. (2009). The consequences of law enforcement officials' failure to record custodial interviews as required by law. Journal of Criminal Law and Criminology, 99, 215-234.

Terrill, W., Paoline, E. A., \& Manning, P. K. (2003). Police culture and coercion. Criminology, 41, 1003-1034.

Thompson, W. C. (2008). Beyond bad apples: Analyzing the role of forensic science in wrongful convictions. Southwestern Law Review, 37, 1027-1050.

Vance, C. R., Jr. (2010). A conviction integrity initiative. Albany Law Review State Constitutional Commentary, 73, 1213-1217.

Volokh, A. (1997). $n$ guilty men. University of Pennsylvania Law Review, 146, 173-211.

Walker, J. L. (1983). The origins and maintenance of interest groups in America. The American Political Science Review, 77, 390-406.

Wells, G. L., \& Olson, E. A. (2001). The other-race effect in eyewitness identification: What do we do about it? Psychology, Public Policy, and Law, 7, 230-246.

Wells, G. L., Steblay, N. K., \& Dysart, J. E. (2012). Eyewitness identification reforms: Are suggestiveness-induced hits and guesses true hits? Perspectives on Psychological Science, 7, 264-271.

Westervelt, S. D., \& Cook, K. J. (2010). Framing innocents: The wrongly convicted as victims of state harm. Crime, Law, and Social Change, 53, 259-275.

Westervelt, S. D., \& Cook, K. J. (2012). Life after death row: Exonerees' search for community and identity. New Brunswick, NJ: Rutgers University Press. 
Westley, W. A. (1970). Violence and the police: A sociological study of law, custom, and morality. Cambridge, MA: MIT Press.

Zalman, M. (2006). Criminal justice system reform and wrongful conviction: A research agenda. Criminal Justice Policy Review, 17, 468-492.

Zalman, M. (2007). The search for criminal justice theory: Reflections on Kraska's Theorizing Criminal Justice. Journal of Criminal Justice Education, 18, 163-181.

Zimring, F. E., Hawkins, G., \& Kamin, S. (2001). Punishment and democracy: Three strikes and you're out in California. New York, NY: Oxford University Press. 